\title{
Physical and Bonding Properties of Opaque Materials for Thermo-Setting Facing Resins
}

\author{
by \\ Minoru NISHIYAMA,* Tomokazu KODAKI,* Shuichi MATSUDAIRA* \\ Yoji YOSHIMIZU,* Hajime OGOSHI,* Kenji HIDAKA* \\ and Masayoshi OHASHI*
}

\section{Introduction}

Opaque materials used with facing resins that block the metallic facing surface color of the metal frame are indispensable for good colour stability of facing resins, and because they are in direct contact with the metal frame they are very important materials regarding the retention of facing resins. Opaque materials, therefore, should have excellent mechanical and bonding properties with the facing surface of the metal frame.

However, few studies have hitherto been reported concerning opaque materials, except KonNo et al's report[1] and ATSUTA et al's[2], respectively concerning their colour, and KASHIWADA's report[3] concerning their physical properties.

In this study, basic experiments were done to determine the physical and bonding properties of opaque materials. The authors selected 5 different kinds of opaque materials on the market to be examined for hardness, mechanical strength, water absorption of set products and their bonding strength with dental alloys.

\section{Materials and Methods}

1. Materials

Table 1 shows opaque materials selected in the present experiments, and facing resins in Table 2.

Table 1 Opaque materials used

\begin{tabular}{|c|c|c|c|c|}
\hline Code & Brand & Manufacturer & Batch No. & Curing condition \\
\hline CA & CAULK Opaquer & THE L.D. CAULK CO. & $\begin{array}{l}\text { Pow. } 72325 \\
\text { Liq. } 060178\end{array}$ & $\begin{array}{l}\text { At } 135^{\circ} \mathrm{C} \text { for } \\
3 \mathrm{~min} \text {. }\end{array}$ \\
\hline TH & Thermoresin & G-C DENTAL IND. CORP. & $\begin{array}{l}\text { Pow. AY3 } \\
\text { Liq. AX22 }\end{array}$ & $\begin{array}{l}\text { At } 80^{\circ} \mathrm{C} \text { for } \\
5 \mathrm{~min} \text {. }\end{array}$ \\
\hline PL & Plastique & $\begin{array}{l}\text { SHOFU DENTAL MFG } \\
\text { Co. LTD. }\end{array}$ & $\begin{array}{l}\text { Pow. } 0337810 \\
\text { Liq. } 027716\end{array}$ & $\begin{array}{l}\text { At } 90^{\circ} \mathrm{C} \text { for } \\
5 \mathrm{~min} \text {. }\end{array}$ \\
\hline $\mathrm{NE}$ & New Metaresin & $\begin{array}{l}\text { WADA PRECISION } \\
\text { DENTAL LAB. }\end{array}$ & $\begin{array}{l}\text { Pow. } 10507 \\
\text { Liq. } 11006\end{array}$ & $\begin{array}{l}\text { At } 80^{\circ} \mathrm{C} \text { for } \\
5 \mathrm{~min} \text {. }\end{array}$ \\
\hline TE & Technical resin & SANKIN IND. CO. LTD. & 520914 & $\begin{array}{l}\text { At } 140^{\circ} \mathrm{C} \cdot 4 \mathrm{~kg} / \\
\mathrm{cm}^{2} \text { for } 5 \mathrm{~min} .\end{array}$ \\
\hline
\end{tabular}

\footnotetext{
*西山実, 小滝友一, 松平修一, 吉水陽二, 大越肇, 日高健二, 大橋正敬：Dept. of Dental Materials, Nihon University School of Dentistry, 1-8-13 Kanda Surugadai Chiyoda-ku Tokyo, Japan
} 
Table 2 Facing resins used

\begin{tabular}{clll}
\hline Brand & \multicolumn{1}{c}{ Manufacturer } & Batch No. & Curing condition \\
\hline Thermo Jel & THE L.D. CAULK Co. & $\begin{array}{l}\text { Pow. } 73267 \\
\text { Liq. } 74137\end{array}$ & At $135^{\circ} \mathrm{C}$ for $10 \mathrm{~min}$. \\
Plastique & SHOFU DENTAL MFG. & $\begin{array}{l}\text { Pow. } 156 \\
\text { Liq. } 23\end{array}$ & $\begin{array}{c}\text { At } 130^{\circ} \mathrm{C} \cdot 4 \mathrm{~kg} / \mathrm{cm}^{2} \\
\text { for } 15 \mathrm{~min} .\end{array}$ \\
\hline
\end{tabular}

2. Measurement of Physical Properties

1) Preparation of Specimens

Test materials, respectively cured by the conditions shown in Table 1, were finished with $\# 600$ carborumdum paper to be specimens with prescribed dimensions $(6.0 \phi \times 6.0 \mathrm{~mm}$ for hardness tests, $6.0 \phi \times 12.0 \mathrm{~mm}$ for compressive strength tests, $45.0 \times 8.0 \times 2.0 \mathrm{~mm}$ for bending strength tests and $20.0 \times 15.0 \times 3.0 \mathrm{~mm}$ for water absorption tests).

Specimens, after being steeped in $37^{\circ} \mathrm{C}$ water for 2 weeks, were used in the experiments shown below.

2) Measurement of Hardness

Rockwell hardness tester (Superficial Type) ${ }^{a}$ was used under the following conditions: load $15 \mathrm{~W}$, loading time 30 seconds and the values were obtained 30 seconds after the removal of the load. 5 specimens of the respective materials were used for measurements, each having 3 measuring points, to calculate average values. 3) Measurement of Compressive Strength

Autograph IS $5000^{\mathrm{b}}$ was used under the following conditions: load cell 2000 $\mathrm{kg}$, load speed $1 \mathrm{~mm} / \mathrm{min}$. Respectively 10 specimens were used for measurements to calculate average values.

4) Measurement of Bending Strength

Autograph IS 5000, together with the device shown in Fig. 1, was used under the following conditions: fulcrum length $30.0 \mathrm{~mm}$, load cell $100 \mathrm{~kg}$ and load speed $1 \mathrm{~mm} / \mathrm{min}$. Respectively 10 specimens were used for measurements to calculate average values.

5) Measurement of Water Absorption

Specimens were vacuum-dried to be of a constant value, and were weighed after being steeped in $37^{\circ} \mathrm{C}$ distillated water to calculate water absorption per unit area. Respectively 2 specimens were used for measurements to calculate average values.

3. Measurement of Bonding Strength

1) Preparation of Substrates

Palladium alloy ${ }^{\mathrm{c}}$ and gold alloy ${ }^{\mathrm{d}}$ were respectively cast by the regular techniques and were finished to be substrates with dimensions shown in Fig. 2 (a). Substrate surfaces were of two types: one intact as it was cast (Casting) and the other

a: Akashi Co. Ltd.'s ARK-MS, Japan

b: Shimazu Co. Ltd., Japan

c: Sankin Palatop 20, Sankin Industry Co., Ltd., Japan

d: $P G A$ 13, Ishifuku Metal Industry Co., Ltd., Japan 


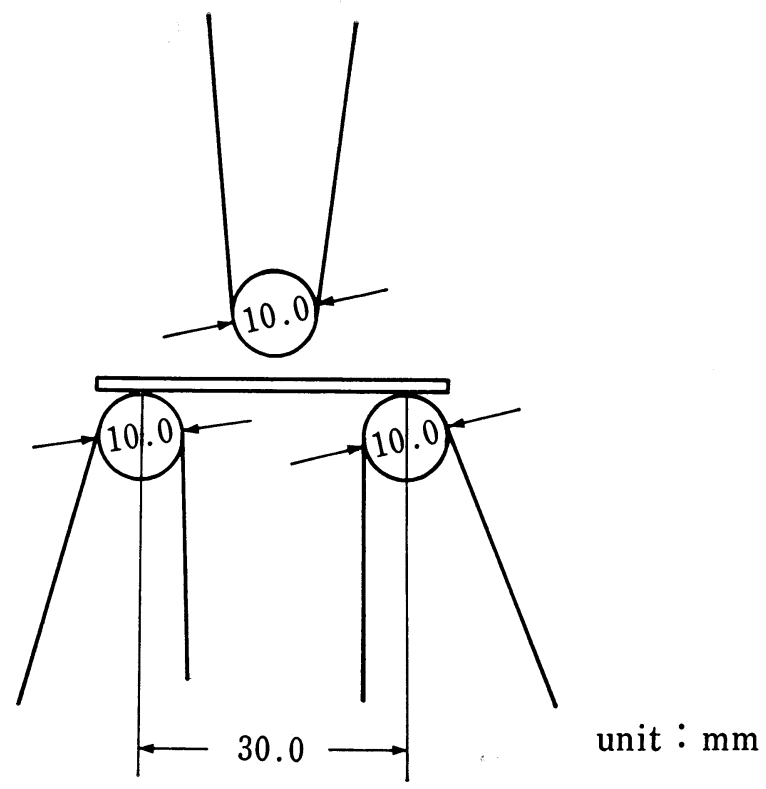

Fig. 1 Bending strength testing device

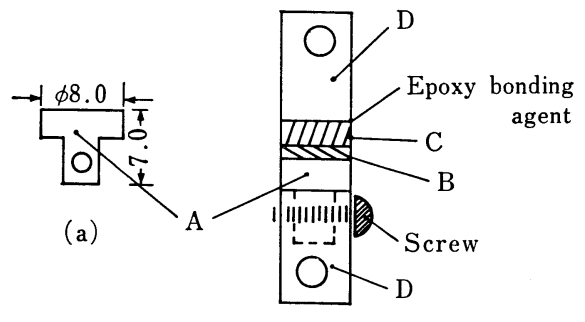

(b)

A : Substrate

B : Opaque material

$C$ : Thermo-setting resin

$\mathrm{D}:$ Brass piece

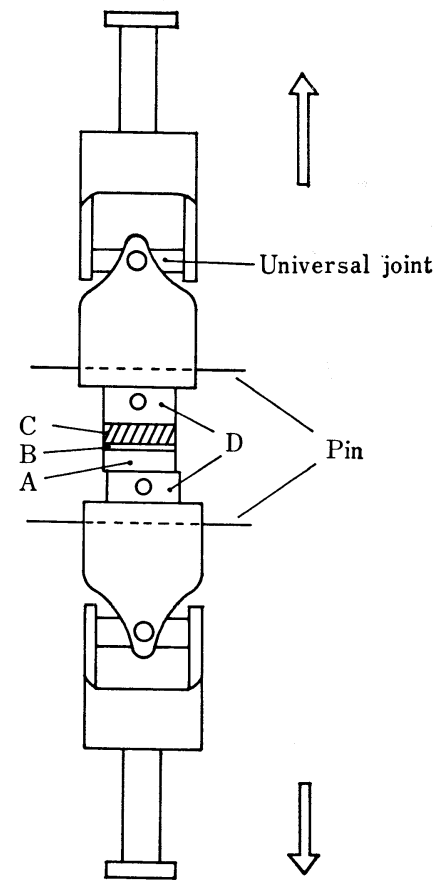

(c)

Fig. 2 Bonding strength testing device 


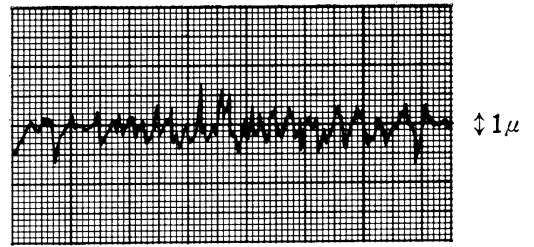

Casting

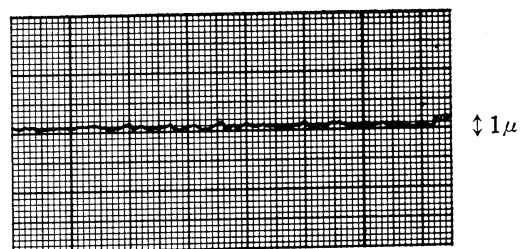

Lapping

Fig. 3 Roughness of substrate surfaces

lapped with $0.3 \mu$ alumina suspension (Lapping). Roughness of the substrate surfaces are shown in Fig. 3.

2) Preparation of Bonding Specimens

Opaque materials were respectively applied to substrate surfaces, $0.5 \mathrm{~mm}$ in thickness, to be cured by the conditions shown in Table 1 . Then, facing resins were put on them to be cured by the conditions shown in Table 2 to be butt joint specimens. The thickness of the resin was adjusted to be approximately $2 \mathrm{~mm}$.

3) Storage Conditions of Specimens

Storage conditions were as follows: 1) steeping in $37^{\circ} \mathrm{C}$ water for one week, 2) steeping in $37^{\circ} \mathrm{C}$ water for 15 weeks and 3) giving thermal cycle treatment. Thermal cycle treatment was given as follows: specimens are first steeped in $37^{\circ} \mathrm{C}$ water for one week, and are then steeped in water kept at $4 \pm 1^{\circ} \mathrm{C}$ and $60 \pm 1^{\circ} \mathrm{C}$ by use of a Parcotester for one minute alternately. The latter treatment, as 1 cycle, was repeated 60 times.

4) Measurement of Bonding Strength

As shown in Fig. 2 (b), substrates were screwed to brass pieces, and with an epoxy bonding agent the facing resin surfaces that had been sufficiently dried were bonded to other brass pieces. After being left for 1 hour at room temperature, the specimens were fixed to the device with a universal joint as shown in Fig. 2 (c), to measure bonding strength. For measurement, an Autograph IS 5000 was used under the following conditions: load cell $100 \mathrm{~kg}$, load speed $1 \mathrm{~mm} / \mathrm{min}$. Respectively 10 specimens were used to calculate average values.

e: Fukui Riken Co. Ltd., Japan 


\section{Results and Discussion}

1. Physical Properties of Set Products

1) Hardness

Fig. 4 shows the results obtained. It is proven that TH is the hardest and PL the softest. TH showed a Rockwell hardness of 68.9, NE 60.3, TE 57.5, CA 50.7, and PL at 400 , the softest, was approximately $60 \%$ as hard as $\mathrm{TH}$.

2) Compressive Strength

Compressive strength was represented by the values of proportional limits. When measuring the compressive strength of resins the moment of failure was often uncertain because of the material itself. Because of this the authors therefore adopted proportional limits whose constant values for comparison were available to represent the compressive strength. Proportional limits were determined from stressstrain curves obtained by measurement.

The results are shown in Fig. 5. It is proven that $\mathrm{TH}$ has the greatest and PL the least compressive strength. That is, TH showed $866 \mathrm{~kg} / \mathrm{cm}^{2}, \mathrm{NE} 671 \mathrm{~kg} / \mathrm{cm}^{2}$,

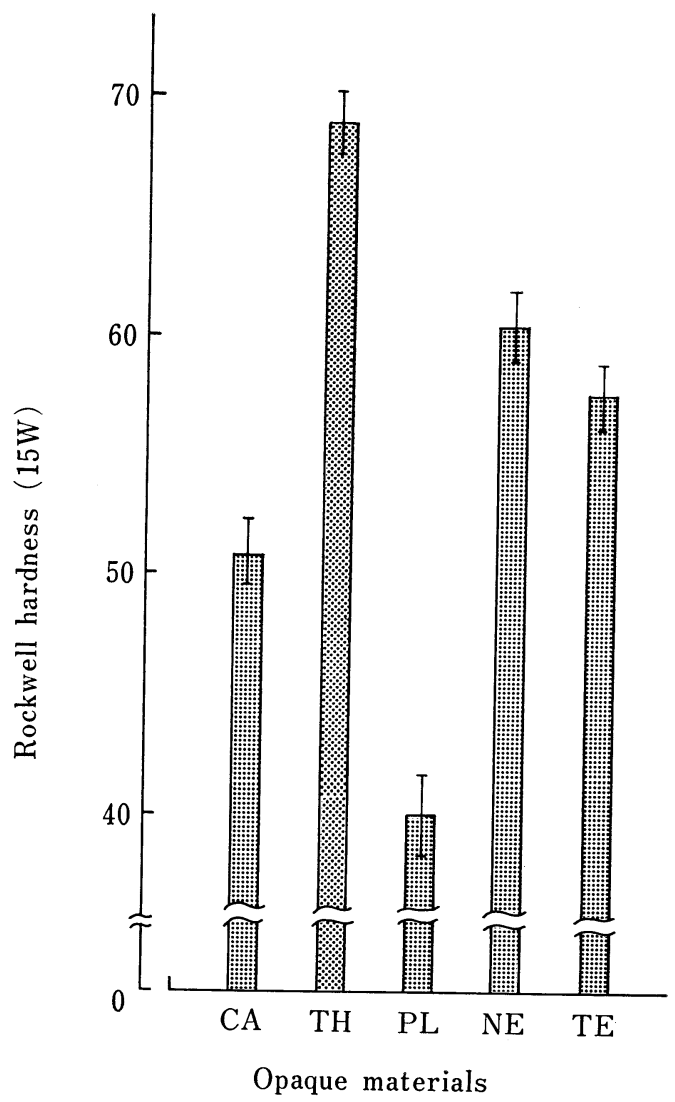

Fig. 4 Hardness of opaque materials 
TE $460 \mathrm{~kg} / \mathrm{cm}^{2}$ and CA $428 \mathrm{~kg} / \mathrm{cm}^{2}$. PL showed the smallest value, $335 \mathrm{~kg} / \mathrm{cm}^{2}$, approximately $40 \%$ that of $\mathrm{TH}$.

3) Bending Strength

Fig. 6 shows the results obtained. It is proven that $\mathrm{TH}$ has the greatest and PL the least bending strength. That is, TH shows $592 \mathrm{~kg} / \mathrm{cm}^{2}, \mathrm{NE} 276 \mathrm{~kg} / \mathrm{cm}^{2}, \mathrm{CA} 203$ $\mathrm{kg} / \mathrm{cm}^{2}$ and TE $195 \mathrm{~kg} / \mathrm{cm}^{2}$. The bending strength of PL couldn't practically be measured because the specimens were fractured when only a minute load was given. 4) Water Absorption

NE showed the smallest and PL the largest water absorption. NE showed 1.02 $\mathrm{mg} / \mathrm{cm}^{2}$, TH $1.11 \mathrm{mg} / \mathrm{cm}^{2}$, NE $1.48 \mathrm{mg} / \mathrm{cm}^{2}$, CA $1.96 \mathrm{mg} / \mathrm{cm}^{2}$, and PL showed a large value, $2.83 \mathrm{mg} / \mathrm{cm}^{2}$, which is approximately 2.7 times that of $\mathrm{NE}$.

As shown above, it is proven that hardness, mechanical strength and water absorption differ according to the kinds of products. Those whose water absorption was small showed larger values in hardness and mechanical strength. This tendency appeared remarkably in TH, and contrarily in PL.

2. Bonding Strength

1) Of those steeped in $37^{\circ} \mathrm{C}$ water for one week

Fig. 8 shows the results obtained. In the substrate surfaces of the Casting and

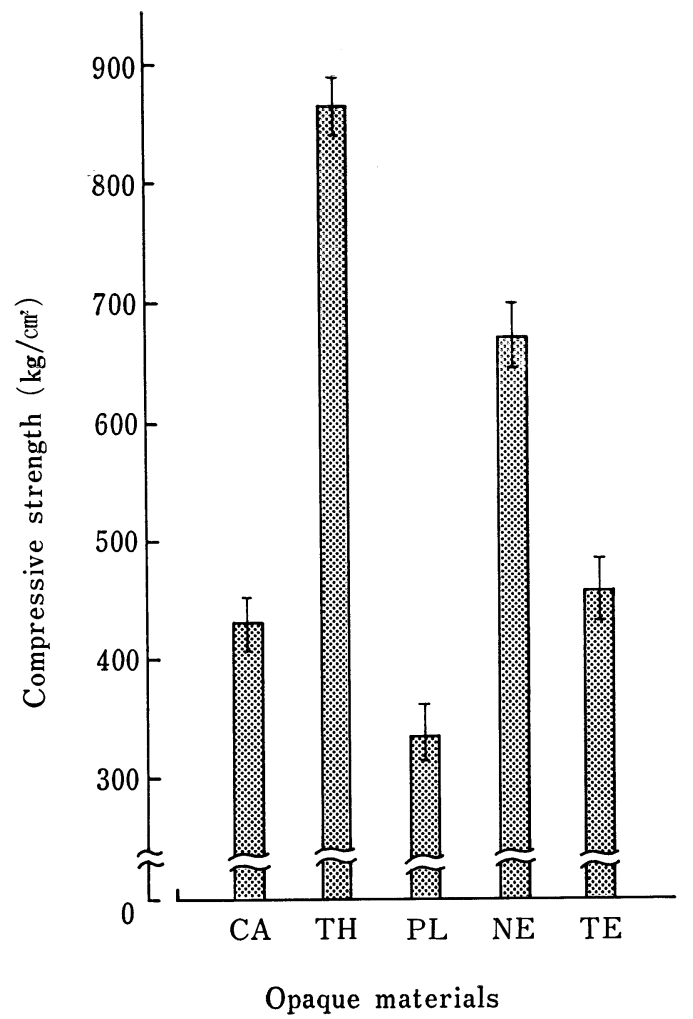

Fig. 5 Compressive strength (proportional limits) of opaque materials 


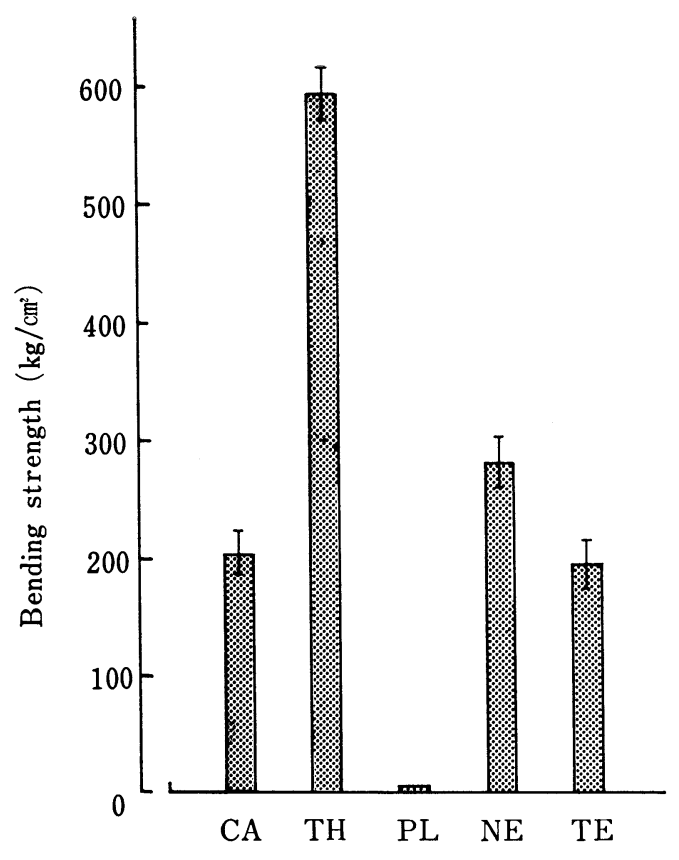

Opaque materials

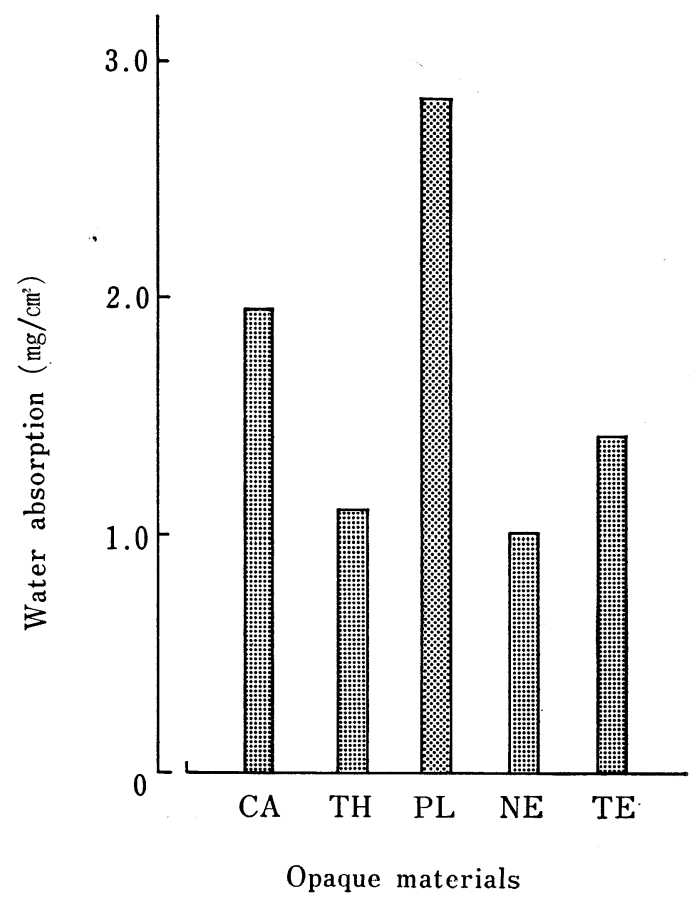

Fig. 6 Bending strength of opaque materials
Fig. 7 Water absorption of opaque materials 


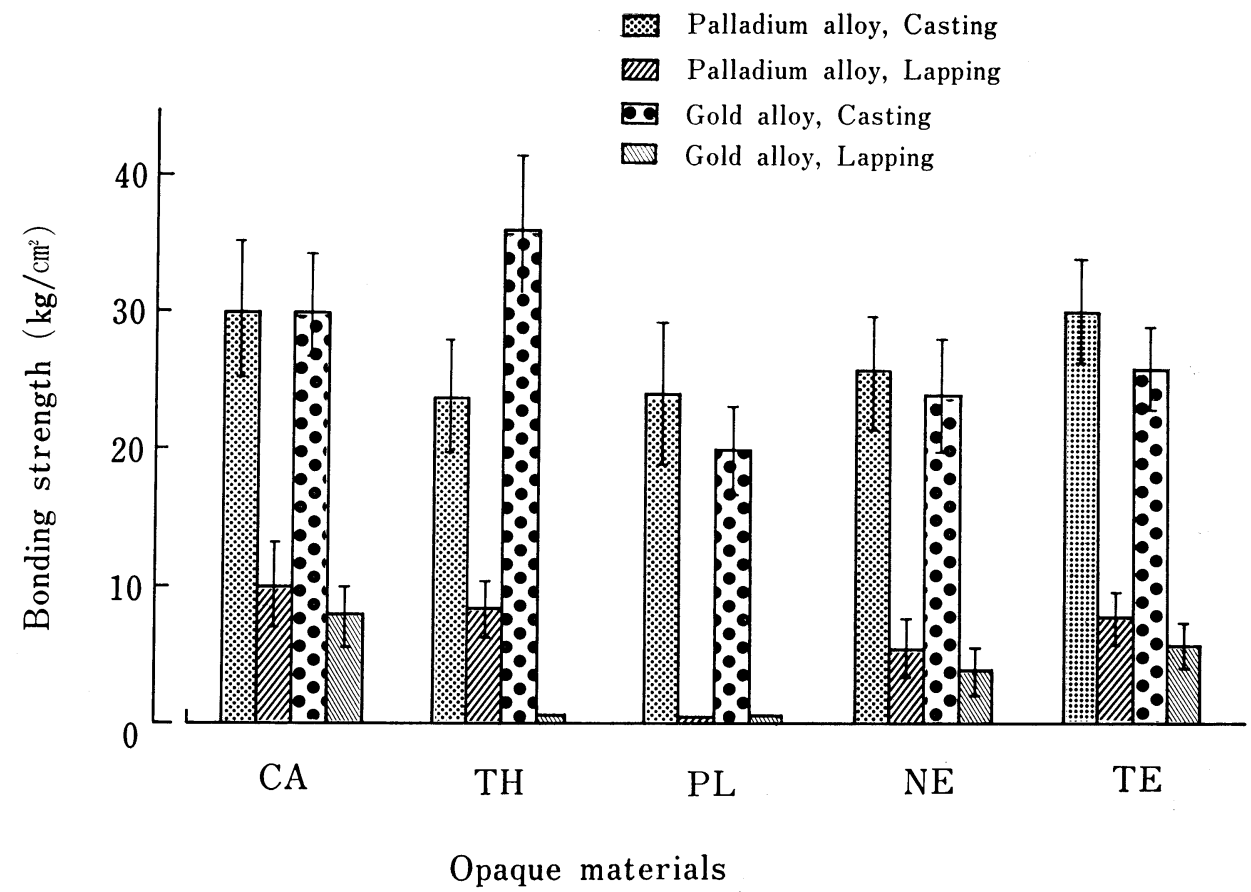

Fig. 8 Bonding strength between opaque materials and alloys (Storage in $37^{\circ} \mathrm{C}$ distilled water for one week)

of the palladium alloy, CA and TE showed $30 \mathrm{~kg} / \mathrm{cm}^{2}, \mathrm{NE} 26 \mathrm{~kg} / \mathrm{cm}^{2}$ and TH and PL $24 \mathrm{~kg} / \mathrm{cm}^{2}$ in bonding strength. Whereas in the gold alloy, TH showed $36 \mathrm{~kg} /$ $\mathrm{cm}^{2}$, CA $30 \mathrm{~kg} / \mathrm{cm}^{2}$, TE $26 \mathrm{~kg} / \mathrm{cm}^{2}$, NE $24 \mathrm{~kg} / \mathrm{cm}^{2}$, and PL $20 \mathrm{~kg} / \mathrm{cm}^{2}$.

In the substrate surfaces of the Lapping and the palladium alloy, CA showed $10 \mathrm{~kg} / \mathrm{cm}^{2}$, TH and TE $8 \mathrm{~kg} / \mathrm{cm}^{2}, \mathrm{NE} 6 \mathrm{~kg} / \mathrm{cm}^{2}$, and PL came off in the water showing no bonding strength. While in the gold alloy, CA showed $8 \mathrm{~kg} / \mathrm{cm}^{2}$, TE $6 \mathrm{~kg} /$ $\mathrm{cm}^{2}, \mathrm{NE} 4 \mathrm{~kg} / \mathrm{cm}^{2}$, and $\mathrm{TH}$ and PL came off in the water also showing no bonding strength.

The majority of failure surfaces of the specimens showing bonding strength were of interface destruction.

The results prove that there is no remarkable difference in the bonding strength due to the kinds of substrate alloys, but it varied to a great degree with a change in the roughness of the substrate surfaces. That is, in the case of the substrate surfaces of the Lapping, it decreased by less than half as compared with that of the Casting.

2) Of those steeped in $37^{\circ} \mathrm{C}$ Water for 15 weeks and Those with Thermal Cycle Treatment Given

Under these conditions the bonding strength couldn't be measured because the opaque materials either separated from the substrate surfaces in the water or during measurement. 
From the results shown above, it is proven that the bonding strength of the opaque materials on the market was extremely feeble. That is, though they showed bonding strength when steeped in water for a short time, no bonding strength could be seen when they were steeped in water for a long time or when thermal cycle treatment was given. It seems that in the case of a one week steep in water, the influence of the water does not appear clearly, but in the case of a long-term steep, up to 15 weeks, the water entering the bonding interfaces causes the opaque material to separate from the substrate.

As to those given thermal cycle treatment, it is presumed that their separation was due to stress on the bonding interfaces caused by the differences in thermal expansion between the opaque materials and the substrates and also by water entering the bonding interfaces.

\section{Conclusion}

The results of this study using 5 kinds of opaque materials on the market were as follows:

1) Hardness and mechanical properties of set products has a close relationship with water absorption. Those that absorbed the least amount of water showed large values of hardness and mechanical properties.

2) There was a clear difference in the bonding strength due to the roughness of the substrate surfaces. The substrate surfaces of the Lappings that showed a bonding strength less than half that of the Castings had no bonding strength.

3) There was a clear difference in bonding strength due to the difference in watersteeping time and thermal cycle treatment. Those steeped in water for a short period showed bonding strength, but those steeped for a long period and those given thermal cycle treatment showed no bonding strength.

\section{References}

[1] Konno, T. et al: Studies on measurement of colour of thermal setting facing resins, Part 2; J.J.P.S., Vol. 20, 114, (1976). (in Japanese)

[2] Atsuta, M. et al: On the colour of facing crown using thermo-setting resins; Practice in Prosthodontics, Vol. 10, No. 3, 185-196, (1977). (in Japanese)

[3] Kashiwada, T.: Physical properties of resins for veneer crown (Part 2); JDAM, Vol. 21, 1-5, (1980). (in Japanese) 